\title{
SOME PRELIMINARY OBSERVATIONS ON ICI 58 834, A NEW PSYCHOTROPIC AGENT, IN MAN
}

ICI $\quad 58 \quad 834 \quad$ (2-(2-ethoxyphenoxymethyl)$2,3,5,6$, tetrohydro- 1,4, oxazine), is a compound whose pharmacology was first studied in animals by Mallion, Todd, Turner, Bainbridge, Greenwood, Madinaveltia, Somerville \& Whittle (1972). Their results suggested that ICI 58834 was a potential psychotropic agent. A method for the estimation of the drug has recently been described (Case, 1973).

The effect of ICI 58834 was investigated in eight university students aged 18-25 years who were fit physically and psychiatrically. A doubleblind cross-over study of placebo and three separate single doses of ICI 58834 were used. One week elapsed between treatments. The following doses of the drug were used: $20 \mathrm{mg}, 40 \mathrm{mg}$ and $80 \mathrm{mg}$. Subjects were assessed immediately before taking the tablet and 1,2 and $4 \mathrm{~h}$ thereafter, when the following tests were carried out using the methods described by Hedges, Hills, Maclay, Newman-Taylor \& Turner (1971); disc dotting (a simple test of hand eye co-ordination), serial subtraction time (a test of mental arithmetic) and critical flicker frequency (a test of central depressant or stimulant activity). After completing each batch of tests, a venous blood sample was taken for the estimation of ICI 58834 by the method of Case (1973).

The mean blood levels obtained with ICI 58834 are shown in Table 1. They suggest that a peak level is reached at about $2 \mathrm{~h}$ after administration. The values obtained are similar to those predicted by Case (1973), being of the order of $0.8(\mu \mathrm{g} / \mathrm{ml}) /(\mathrm{mg} / \mathrm{kg})$ dose. There was no effect of the drug on any of the tests at any dose studied. This suggests that at these doses, in normal subjects, ICI 58834 has no effect on hand eye
Table 1 Mean blood levels $(\mu \mathrm{g} / \mathrm{ml})$ obtained with three different doses of $\mathrm{ICI} 58834$ in eight subjects

$\begin{array}{cccc}\text { Dose of ICI } 58834 & 1 h & 2 h & 4 h \\ 20 \mathrm{mg} & 0.10 & 0.14 & 0.19 \\ 40 \mathrm{mg} & 0.23 & 0.36 & 0.25 \\ 80 \mathrm{mg} & 0.54 & 0.74 & 0.66\end{array}$

co-ordination nor any marked stimulant or depressant action on the CNS.

We thank Dr P. Bayliss of I.C.I. Laboratories Ltd for supplying ICI 58834 and arranging for estimation of its plasma levels.

\section{MARILYN KIRBY \& P. TURNER}

Department of Clinical Pharmacology, St Bartholomew's Hospital, London EC1A $7 B E$

Received October 12, 1973

\section{References}

CASE, D.E. (1973). Gas-liquid chromatograph estimation in blood of ICI 58834 . J. Pharm. Pharmac., 25, $800-802$.

HEDGES, A., HILLS, M., MACLAY, W.P., NEWMANTAYLOR, A.J. \& TURNER, P. (1971). Some central and peripheral effects of meclastine, a new antihistaminic drug in man. J. Clin. Pharmac., 11, 112-119.

MALLION, K.B., TODD, A.H., TURNER, R.W., BAINBRIDGE, J.G., GREENWOOD, D.T., MADINAVELTIA, J., SOMERVILLE, A.R. \& WHITTLE, B.A. (1972). 2-(2-ethoxyphenoxymethyl)tetrahydro-1,4,oxazine hydrochloride, a potential psychotropic agent. Nature, Lond., 238, 157-158.

\section{ENTEROHEPATIC CIRCULATION OF PRACTOLOL IN MAN}

Following the administration of practolol to various animals, Scales \& Cosgrove (1970) were able to detect its appearance in bile, together with some of its metabolites. Human pharmacokinetic studies also led to the suggestion that practolol might enter the enterohepatic circulation in man (Aellig, Prichard \& Scales, 1970). Carruthers,
Kelly, McDevitt \& Shanks (1974) observed small peaks in the plasma practolol decay curves about $2 \mathrm{~h}$ after intravenous administration to volunteers. Studies on human volunteers in this department also showed similar secondary peaks following intravenous injection (Kaye \& Kumana, unpublished observations). When obtained with other 
drugs, e.g. carbenoxolone, such secondary peaks have been taken to indicate enterohepatic recirculation (Downer, Galloway, Horwich \& Parke, 1970). For these reasons a patient with an indwelling T-tube in the common bile duct was given practolol to determine whether it appeared in bile.

The patient was a 34-year-old man, admitted to a surgical ward on account of abdominal pain and tenderness. During his stay in hospital a diagnosis of polycythaemia ruba vera was made and proven on the basis of red cell mass studies. Over the next few weeks he became jaundiced and bilirubin appeared in his urine. A cholystogram revealed a non-functioning gall bladder and an intravenous cholangiogram showed the appearance of chronic calculous cholecystitis. He was treated with radioactive phosphorus, and two weeks later had cholecystectomy and exploration of his biliary tract, following which a T-tube was left in situ in the common bile duct. His condition improved after surgery though subsequent cholangiograms followed by another operation confirmed that at the time of the present investigation his bile ducts still contained calculi. His serum bilirubin fell from $12 \mathrm{mg} \%$ at the time of his first operation to $1.7 \mathrm{mg} \%$ after three weeks, at which time this study was undertaken.

The patient gave his informed consent to allow the present investigation, at which time he was normotensive and his electrocardiogram showed no abnormality. $\mathrm{He}$ gave no past history of asthma. Results of various routine tests carried out just prior to this study were as follows: blood count: haemoglobin $12 \mathrm{~g} \%$, P.C.V. $36 \%$, redblood-cell count and white-blood-cell count within normal limits, estimated number of plateletsnormal; plasma urea and electrolytes-normal; creatinine clearance $104 \mathrm{ml} / \mathrm{min}$; liver function tests: serum-bilirubin $1.7 \mathrm{mg} \%$, alkaline phospha- tase 131 I.U., S.G.O.T. 164 Babson units, total protein $6.4 \mathrm{~g} \%$.

A dose of $1 \mathrm{mg} / \mathrm{kg}$ of intravenous practolol (71 mg) was administered over $5 \mathrm{~min}$, and plasma samples were taken from the patient at intervals thereafter. Urine and bile were also collected over the next $24 \mathrm{~h}$ and their respective volumes measured. The study was repeated after $48 \mathrm{~h}$ with oral practolol $(200 \mathrm{mg})$ in the form of a capsule. The patient experienced no untoward symptoms.

Practolol concentrations in plasma, urine and bile were determined spectrophotometrically by a method based on that described by Fitzgerald \& Scales (1968). Alkalinized samples of the three biological fluids were extracted with ethyl acetate, and after back extraction into dilute acid followed by acid hydrolysis, a blue colour (peak absorption at $580 \mathrm{~nm}$ ) was obtained on diazotization with $N$-1-naphthylethylenediamine. Standard curves were prepared by adding known amounts of practolol to normal plasma, normal urine and the patient's own pre-trial bile, and measuring the absorption of the blue colour ultimately obtained. Concentrated ethyl acetate extracts of alkalinized bile (Table 1) were subjected to thin layer chromatography on glass plates pre-coated with silica gel $\mathrm{G}_{254}$ (Camag Ltd) in solvent mixtures $\mathrm{A}$, methanol-ammonia (sp. gr. 0.88), (99:1 by volume); B, ethanol-water-ammonia (sp. gr. $0.88),(85: 3: 3$ by volume) and $C$, butan-1-olwater-ammonia (sp. gr. 0.88), $(90: 10: 1$ by volume). The plates were examined under ultraviolet light, practolol appearing as a dark spot on a green background.

The results are summarized in Table 1 and Figures 1 and 2. Pre-trial plasma, urine and bile contained no practolol. Chromatography of extracts of bile obtained after practolol administration demonstrated the presence of a compound having similar $R_{\mathrm{F}}$ values in solvent mixtures $\mathrm{A}$, B and $\mathrm{C}$ to those of practolol. There were no other

Table 1 Data on bile and urine collected after practolol administered i.v. or orally to one subject

\begin{tabular}{|c|c|c|c|c|c|c|c|}
\hline \multicolumn{4}{|c|}{ After (71 mg, i.v.) practolol } & \multicolumn{4}{|c|}{ After $(200 \mathrm{mg}$, oral) practolol } \\
\hline \multirow{2}{*}{$\begin{array}{c}\text { Time of sample } \\
\text { (h) }\end{array}$} & \multicolumn{2}{|c|}{ Bile } & \multirow{2}{*}{$\begin{array}{c}\text { Urine } \\
\text { Practolol } \\
\text { (mg) }\end{array}$} & \multirow{2}{*}{$\begin{array}{c}\text { Time of sample } \\
\text { (h) }\end{array}$} & \multicolumn{2}{|c|}{ Bile } & \multirow{2}{*}{$\begin{array}{c}\text { Urine } \\
\text { Practolol } \\
\text { (mg) }\end{array}$} \\
\hline & $\begin{array}{c}\text { Practolol } \\
(\mu \mathrm{g} / \mathrm{ml})\end{array}$ & $\begin{array}{c}\text { Volume } \\
\text { (mI) }\end{array}$ & & & $\begin{array}{c}\text { Practolol } \\
(\mu g / m /)\end{array}$ & $\begin{array}{c}\text { Volume } \\
\text { (mI) }\end{array}$ & \\
\hline $\begin{array}{l}0-2 \\
2-4 \\
4-6 \\
6-24\end{array}$ & $\begin{array}{l}\text { ND } \\
\text { ND } \\
\text { ND } \\
0.76\end{array}$ & $\begin{array}{c}1 \\
2 \\
0.5 \\
23\end{array}$ & $\begin{array}{r}16.13 \\
7.04 \\
7.90 \\
29.50\end{array}$ & $\begin{array}{l}0-2 \\
2-4 \\
4-6 \\
6-8 \\
8-24\end{array}$ & $\begin{array}{c}0.18 \\
6.36 \\
3.62 \\
- \\
2.46\end{array}$ & $\begin{array}{c}0.2 \\
21^{*} \\
2 \\
\mathrm{Nil} \\
121^{*}\end{array}$ & $\begin{array}{r}2.94 \\
26.50 \\
24.28 \\
18.98 \\
75.34\end{array}$ \\
\hline
\end{tabular}

ND, not detected.

* Also examined by thin layer chromatography. 


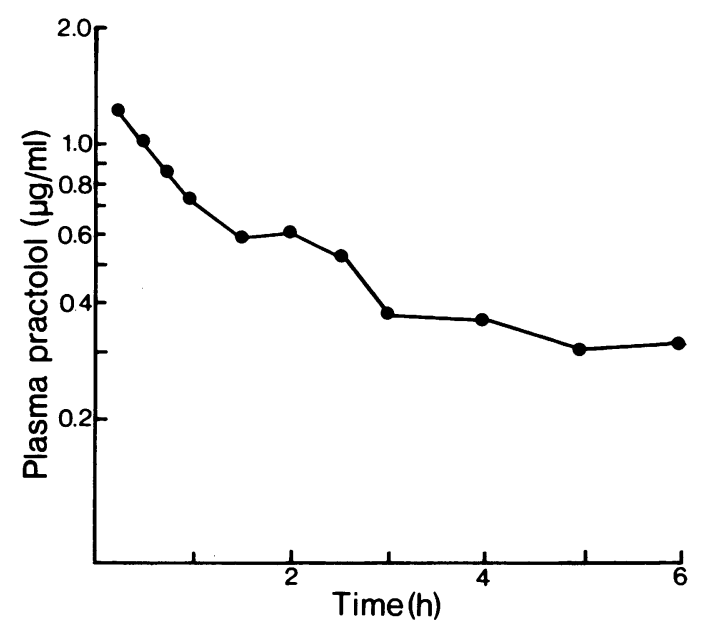

Fig. 1 Plasma levels after the injection of $71 \mathrm{mg}$ of practolol intravenously over 5 minutes. End of injection 0 hours.

spots present in these extracts which were not present in extracts of control bile. The concentration of practolol in those bile samples subjected to enzymic or acid hydrolysis was not increased, suggesting the absence of a glucuronide or acid hydrolysable conjugate of practolol.

A blue colour (maximum absorption at $580 \mathrm{~nm}$ ) was ultimately obtained only from extracts of bile collected after practolol administration, or when authentic practolol had been added to pre-trial bile. From these observations and the chromatographic evidence it was concluded that the compound detected and measured in bile was free practolol.

It is appreciated that this study involved only a single patient and that he was recovering from obstructive jaundice and had recently undergone an operation. He had no gall bladder, and so assuming a constant rate of bile formation a constant fraction of the bile flow was expected to be sampled. In fact, the volume of bile collected during each two hourly period was variable, suggesting that the patient had intermittent biliary obstruction. The finding of residual biliary calculi at subsequent surgery lent further weight to this possibility. The inconstancy of bile flow was probably further accentuated by the consequent failure to re-absorb bile salts which act as potent choleretics. Thus, when hardly any bile was recovered from the sampling tube, as in the first $6 \mathrm{~h}$ after intravenous practolol, whatever bile was present might have emerged from the dead space of the tube and so not represent bile formation

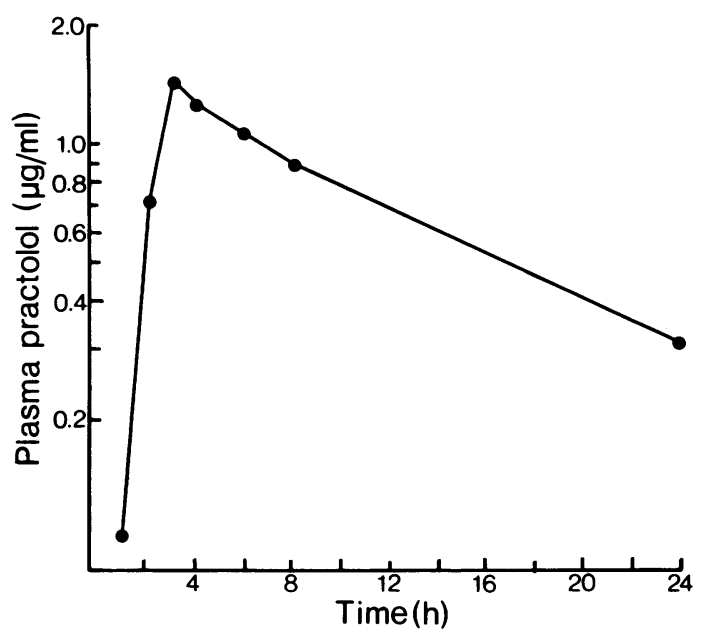

Fig. 2 Plasma levels after $200 \mathrm{mg}$ practolol taken orally. Time of swallowing capsule 0 hours.

during the time of collection.

With these reservations, it should be noted that after intravenous practolol, the concentration in the 6-24 $\mathrm{h}$ aliquot of bile was higher than the plasma concentration at any time after 1 hour. After oral practolol the biliary concentration was also consistently higher than in the plasma. This was so even between 8 and $24 \mathrm{~h}$ after taking the drug, at times when the practolol concentration in the portal vein was unlikely to be higher than in any other vein, and by which time $50 \%$ of the practolol ultimately recovered from the $24 \mathrm{~h}$ urine sample had already been excreted.

The bile secreted contained no detectable glucuronides or acid hydrolysable conjugates of practolol and only a moderately high concentration of free drug. Even if the patient was producing up to 1 litre of bile in $24 \mathrm{~h}$ and assuming that the mean practolol concentration of the same to be the highest practolol concentration actually recorded in his bile, the total biliary practolol excretion could scarcely have affected the plasma concentration. Therefore, the secondary peak in the plasma levels occurring after intravenous practolol (Fig. 1) was unlikely to be due to enterohepatic re-circulation. Nevertheless, the results obtained show that practolol takes part in the enterohepatic circulation and also raise the possibility of its active secretion into bile.

We thank Mr I. Todd and Mr A.P. Ross for allowing us to study their patient, and Professor P. Turner and Dr M.L. Clarke for their helpful advice and encouragement. We also thank the British 
Heart Foundation and Board of Governors of St Bartholomew's Hospital for financial support.

\section{C.M. KAYE \& C.R. KUMANA}

Departments of Clinical Pharmacology and Cardiology, St Bartholomew's Hospital, London ECIA $7 B E$

Received December 20, 1973

\section{References}

Aellig, W.H., PRIChaRd, B.N.C. \& SCAlES, B. (1970). Blood levels of practolol following intravenous administration. Br. J. Pharmac., 40, 573P.
CARRUTHERS, S.G., KELLY, J.G., McDEVITT, D.G. \& SHANKS, R.G. (1974). Studies on the parenteral administration of practolol. Br. J. clin. Pharmac., 1, $179 P$.

DOWNER, H.D., GALLOWAY, R.W., HORWICH, L. \& PARKE, D.V. (1970). The absorption and excretion of carbenoxolone in man. J. Pharm. Pharmac, 22, $479-487$.

FIT ZGERALD, J.D. \& SCALES, B. (1968). Effect of a new adrenergic beta-blocking agent (ICI 50,172) on heart rate in relation to its blood levels. Int. $Z$. Klin. Pharmac. Ther. Toxik., 1, 467-474.

SCALES, B. \& COSGROVE, M.B. (1970). The metabolism and distribution of the selective adrenergic beta-blocking agent, practolol. J. Pharmac. exp. Ther., 175, 338-347. 